Published in final edited form as:

Environ Int. 2014 October ; 71: 81-87. doi:10.1016/j.envint.2014.06.006.

\title{
Prenatal exposure to mixtures of xenoestrogens and repetitive element DNA methylation changes in human placenta
}

\author{
Nadia Vilahur ${ }^{1,2,3,4}$, Mariona Bustamante ${ }^{1,2,3,4}$, Hyang-Min Byun ${ }^{5}$, Mariana F. \\ Fernandez $^{4,6,7}$, Loreto Santa Marina ${ }^{4,8,9}$, Mikel Basterrechea ${ }^{4,8,9}$, Ferran Ballester ${ }^{4,10,11}$, \\ Mario Murcia $4,10,11$, Adonina Tardón ${ }^{4,12}$, Ana Fernández-Somoano ${ }^{4,12}$, Xavier Estivill $2,3,4,13$, \\ Nicolas Olea ${ }^{4,6,7}$, Jordi Sunyer ${ }^{1,2,4,13}$, and Andrea A. Baccarelli ${ }^{5}$ \\ ${ }^{1}$ Center for Research in Environmental Epidemiology (CREAL), Barcelona, Catalonia, Spain \\ ${ }^{2}$ Hospital del Mar Medical Research Institute (IMIM), Barcelona, Catalonia, Spain \\ ${ }^{3}$ Genomics and Disease Group, Bioinformatics and Genomics Program, Center for Genomic \\ Regulation (CRG), Barcelona, Catalonia, Spain \\ ${ }^{4}$ Spanish Consortium for Research on Epidemiology and Public Health (CIBERESP), Spain \\ ${ }^{5}$ Laboratory of Environmental Epigenetics, Exposure Epidemiology and Risk Program, \\ Department of Environmental Health, Harvard School of Public Health, Boston, MA, USA \\ ${ }^{6}$ Department of Radiology, Centro de Investigación Biomédica, University of Granada, Granada, \\ Spain \\ ${ }^{7}$ Instituto de Investigación Biosanitaria de Granada, Hospital Universitario San Cecilio, Granada, \\ Spain \\ ${ }^{8}$ Subdirección de Salud Pública de Gipuzkoa, Department of Health of the Basque, Spain \\ ${ }^{9}$ Health Research Institute, BIODONOSTIA, Basque Country, Spain \\ ${ }^{10}$ Centre for Public Health Research (CSISP-FISABIO), Valencia, Spain \\ ${ }^{11}$ University of Valencia, Valencia, Spain \\ ${ }^{12}$ University of Oviedo, Oviedo, Asturias, Spain \\ ${ }^{13}$ Department of Health and Life Sciences, University Pompeu Fabra (UPF), Barcelona, \\ Catalonia, Spain
}

\section{Abstract}

\footnotetext{
(C) 2014 Elsevier Ltd. All rights reserved.

Corresponding Author: Nadia Vilahur, Center for Research in Environmental Epidemiology (CREAL), C/Doctor Aiguader, 83. 08003 Barcelona, Spain., Phone: +34933160177 nvilahur@creal.cat.

Competing interests: The authors have no conflicts of interest, financial or otherwise, related to this manuscript.

Publisher's Disclaimer: This is a PDF file of an unedited manuscript that has been accepted for publication. As a service to our customers we are providing this early version of the manuscript. The manuscript will undergo copyediting, typesetting, and review of the resulting proof before it is published in its final citable form. Please note that during the production process errors may be discovered which could affect the content, and all legal disclaimers that apply to the journal pertain.
} 
Background-Prenatal exposure to endocrine disrupting compounds (EDCs) has previously shown to alter epigenetic marks.

Objectives-In this work we explore whether prenatal exposure to mixtures of xenoestrogens has the potential to alter the placenta epigenome, by studying DNA methylation in retrotransposons as a surrogate of global DNA methylation.

Methods-The biomarker Total Effective Xenoestrogen Burden (TEXB) was measured in 192 placentas from participants in the longitudinal INMA Project. DNA methylation was quantitatively assessed by bisulfite pyrosequencing on 10 different retrotransposons including 3 different long interspersed nuclear elements (LINEs), 4 short interspersed nuclear elements (SINEs) and 3 human endogenous retrovirus (HERVs). Associations were tested using linear mixed-effects regression models and sex interaction was evaluated.

Results-A significant sex interaction was observed for $A l u Y b 8$ (p value for interaction $<0.001$, significant at Bonferroni corrected p-value threshold of 0.0025). Boys with the highest TEXBalpha levels of exposure (third tertile) presented on average a decrease of $0.84 \%$ in methylation compared to those in the first tertile ( $\mathrm{p}$ value $<0.001$ ), while no significant effects were found in girls ( $\mathrm{p}$ value $=0.134)$.

Conclusions-Our findings suggest that boys may be more susceptible to the effect of exposure to xenoestrogens during prenatal development, producing shifts in DNA methylation of certain sensitive genomic repetitive sequences in a tissue important for fetal growth and development.

\section{Keywords}

xenoestrogens; placenta; sex; repetitive elements; global DNA methylation; biomarker; TEXB

\section{INTRODUCTION}

Endocrine disrupting compounds (EDCs) are exogenous compounds or mixtures that alter function(s) of the endocrine system and consequently cause adverse health effects in an intact organism, or its progeny, with the highest concerns being raised for reproductive and neurobehavioral abnormalities, immune function and cancer risk (WHO 2002). Among EDCs, xenoestrogens are a subgroup of hormonally active compounds that interfere with the estrogenic signaling pathway. They can either affect the levels of endogenous hormone (Prins et al. 2008; Tabb and Blumberg 2006), or mimic estrogen action and bind with different affinities to the estrogen receptors ERa or ER $\beta$, that function as ligand-activated transcriptional factors, and modify the pattern of expression of specific target genes (Bulzomi and Marino 2011). Xenoestrogens have been extensively used not only in agriculture but also in the manufacture of materials, products and goods like resins, textiles, plastics, cosmetics, flame retardants or insulators. They may also arise as by-products of industrial processes. A variety of adverse health effects have been described in relation to environmental exposure to single xenoestrogens (Arrebola et al. 2013b; Ibarluzea Jm et al. 2004; Valvi et al. 2013). Many xenoestrogens are persistent organic pollutants (POPs) and bioaccumulate in lipids. Therefore, exposure in human populations, even at low-doses, is most likely ubiquitous, persistent and occurs in complex mixtures (Arrebola et al. 2013a; Fucic et al. 2012), with effects that may not be predictable when analyzing single 
compounds independently (Webster 2013). As stated by the latest World Health Organization (WHO) report on endocrine disrupting chemicals "...there is emerging evidence that many chemicals may act additively and, each at levels without individual effect, could act together to cause health problems" (WHO 2013).

Several studies have evidenced the transplacental transfer of xenoestrogens including POPs, flame retardants and arsenic, which only weakly or fail to bind to a-fetoprotein, the fetal form of serum albumin (Frederiksen et al. 2010; Pilsner et al. 2012; Tan et al. 2009). Exposure in utero has been related to a number of adverse health endpoints in children, including a higher risk for overweight, alterations in psychomotor and cognitive development or urogenital abnormalities in male newborns (Forns et al. 2012; Palmer et al. 2009; Puertas et al. 2010; Valvi et al. 2013), and several studies have reported sex specific effects occurring by mechanisms that remain poorly understood (Fernandez et al. 2007; Papadopoulou et al. 2013; Vafeiadi et al. 2013; Valvi et al. 2012 ).

A number of in vivo and in vitro studies and a few human investigations have shown effects of EDCs, mainly pesticides, on different epigenetic marks including DNA methylation as reviewed by Collotta et al. (2013) (Collotta et al. 2013), and there is some evidence in animal models of transgenerational inheritance of epigenetic alterations and diseaseassociated states due to EDCs exposure (Guerrero-Bosagna et al. 2012; Guerrero-Bosagna et al. 2013; Manikkam et al. 2013; Skinner et al. 2013).

Repetitive elements are genomic DNA sequences that account approximately for half of the human genome and have often been studied as surrogates of global DNA methylation (Klose and Bird 2006; Lander et al. 2001; Tajuddin et al. 2013; Wilhelm et al. 2010). A group of these sequences, called retrotransposons, propagate themselves by RNA mediated transposition (Rogers 1983) and constitute an interesting source of human genomic variation, genomic instability and occasionally, disease (Callinan and Batzer 2006; Wolff et al. 2010). Among retrotransposons, the best studied families are the long interspersed nuclear elements (LINEs), the short interspersed nuclear elements (SINEs), and the human endogenous retrovirus (HERV). Most epidemiological studies in humans have analyzed methylation in LINE1 and AluSx subfamilies in relation to environmental exposures (Kile et al. 2012; Kim et al. 2010; Rusiecki et al. 2008; Wright et al. 2010). Additional repetitive element subfamilies have been described in humans differing in their nucleotide sequence and estimated evolutionary age of insertion in the human genome. These subfamilies present heterogeneous methylation patterns, which may lead to varying degrees of regulation and susceptibility to environmental stressors like, for example, airborne pollutants or tobacco smoke during pregnancy (Breton et al. 2009; Byun et al. 2013).

The purpose of the present study is to explore whether prenatal exposure to mixtures of xenoestrogens can affect DNA methylation of several retrotransposons in human placental tissue and if effects differ among boys and girls. 


\section{MATERIAL AND METHODS}

\subsection{Study population}

The INMA (Infancia y Medio Ambiente) Project, is a population-based longitudinal birth cohort, including mother and children pairs from different Spanish regions, aiming at understanding the effects of exposure to prenatal and early postnatal environmental factors on different health outcomes in children including growth trajectories, allergies, asthma and neurodevelopment. Detailed information on recruitment has been published elsewhere (Guxens et al. 2012). This study was based on INMA individuals from the cohorts of Asturias, Gipuzkoa Sabadell and Valencia. DNA methylation was analyzed on a total of 192 placentas randomly selected among those of Caucasian origin, having TEXB biomarker measurement available as well as with maximal completeness of information on covariates during pregnancy, and ensuring a similar male to female ratio ( 97 males vs 95 females).

Mothers were orally informed and prior to delivery provided written informed consent of their participation in the study, which was approved by the Institutional Review Board of all the Institutions involved.

\subsection{Total Effective Xenoestrogen Burden}

The Total Effective Xenoestrogen Burden is a biomarker of the combined estrogenic effect of environmental chemicals which has previously been studied in relation to the risk for several human diseases including anomalies of sexual maturation in males, breast cancer and Type 2 diabetes and common phenotypes such as birth weight (Arrebola et al. 2013b; Fernandez et al. 2007; Ibarluzea Jm et al. 2004; Vilahur et al. 2013b).

INMA placentas were randomly collected at the time of delivery in the different hospitals of recruitment and after physical examination they were weighted without deciduas basalis and chorionic plate and frozen at $-20^{\circ} \mathrm{C}$ or $-80^{\circ} \mathrm{C}$. No information was available about the timeto-storage after delivery for each placenta, but a maximum of 6 hours was estimated. Then, they were transferred in dry ice to the Biobank at the San Cecilio University Hospital (HUSC) in Granada and stored at $-80^{\circ} \mathrm{C}$.

Before performing the TEXB biomarker assay, each placenta was slightly defrosted and cut in half, and one of the halves was placed in the glass container of a mixer (Büchi Mixer B-400 Büchi Laboratories AG, Flawil, Switzerland) and homogenized to ensure representativity of the whole placenta in the aliquoting process. The remaining half of the placenta was stored again at $-80^{\circ} \mathrm{C}$. The methodology has been published previously (Fernandez et al. 2007). Briefly, $0.4 \mathrm{~g}$ of placenta homogenate was extracted with hexane and eluted in a glass column filled with Alumine. The process was performed per quadruplicate for each placenta sample (total weight: $1.6 \mathrm{~g}$ of placenta). The pooled concentrated eluate was injected into the preparative high-pressure liquid chromatography (HPLC). The HPLC method was developed to efficiently separate according to their polarity organohalogenated lipophilic xenoestrogens (HPLC-alpha fraction) from endogenous hormones (HPLC-beta fraction), using a normal-phase column. The combined estrogenic effect of both HPLC fractions was then tested in the E-Screen bioassay for estrogenicity; a proliferative in vitro assay using MCF-7 human breast cancer cells. Each sample was 
assayed in triplicate with a negative (vehicle) and positive (estradiol) control, as described in detail by Fernandez et al. (Fernandez et al. 2007). The proliferative effect (PE) was calculated as the ratio between the highest cell yield obtained with $100 \mathrm{pM}$ of estradiol and the proliferation of hormone-free control cells. The PE of alpha and beta fractions was referred to the maximal effect obtained with estradiol and transformed into estradiol equivalent units (Eeq) by reading from a dose-response curve prepared using estradiol (concentration range $0.1 \mathrm{pM}$ to $10 \mathrm{nM}$ ) and was expressed as TEXB-alpha and TEXB-beta values in Eeq pM per milliliter (pM Eeq/ml) and Eeq pM per gram of tissue (pM Eeq/g) (Fernandez et al. 2007).

The limit of detection (LOD) was defined as the concentration needed to produce a significantly different proliferative effect from that observed in control cells ( $0.1 \mathrm{pM}$ Eeq/ $\mathrm{ml})$. A concentration equal to $0.05 \mathrm{pM} \mathrm{Eeq} / \mathrm{ml}$ was assumed for samples with TEXB values below the LOD $(n=31,16.15 \%)$.

The estrogenicity of the alpha-fraction, which contains no endogenous sex-hormones or polar xenoestrogens (beta-fraction), can be considered a marker of the TEXB of persistent environmental organohalogenated estrogens (Fernandez et al. 2007).

\subsection{Placental biopsying and DNA extraction}

Half placentas were kept frozen at $-80^{\circ} \mathrm{C}$ at the Hospital Universitario San Cecilio (HUSC) Biobank in Granada. In order to obtain biopsies for DNA extraction, placentas were physically examined to determine the fetal side, which was not always easily recognizable. To avoid basal plate contamination (maternal side) and exclude the chorionic plate (fetal membranes amnios and chorion) and to ensure as homogeneous sampling procedures across samples as possible, biopsies of 1 to $2 \mathrm{~cm}^{3}$ were obtained from the inner region (in relation to the dorsal and ventral sides) from the middle of the placenta (in terms of distance from the outer part to the center), similarly to what has been proposed by other authors (Janssen et al. 2012). During the whole procedure samples were handled on ice to prevent complete defrosting of the tissue and biopsies were immediately transferred in labeled tubes kept in dry ice and stored at $-80^{\circ} \mathrm{C}$.

Placental biopsies were rinsed twice in $0.8 \mathrm{~mL}$ PBS $0.5 \mathrm{X}$ during 5 minutes prior to DNA extraction to remove traces of maternal blood. On average, around $20 \mu \mathrm{g}$ of good quality genomic DNA was obtained from $25 \mathrm{mg}$ of starting material using the DNeasy Blood \& Tissue Kit (Qiagen, Valencia, CA, USA). Sample concentrations and purity ratios (260/230 and 260/280) were measured using a NanoDrop spectrophotometer device (Thermo Scientific, Waltham, MA, USA). Additionally, $100 \mathrm{ng}$ of DNA were loaded on $1.3 \%$ agarose gels with SYBR safe staining (Invitrogen, Carlsbad, CA, USA) to visually check for DNA degradation (smear bands or bands below $10,000 \mathrm{bp}$ ). The isolated genomic DNA presented a good DNA quality and was stored at $-20^{\circ} \mathrm{C}$ for further quantification of DNA methylation. 


\subsection{Global DNA methylation}

We measured placental genome-wide levels of DNA methylation in repetitive elements as a proxy of global DNA methylation. Bisulfite pyrosequencing was used to quantitatively measure DNA methylation levels of 4 LINEs (L1PA5, L1PA2, L1HS and L1Ta), 3 SINEs (AluSx, AluYb8 and Alud6) and 3 HERV (MLT1D, ERV1 and ERV9) in 192 placenta samples.

First, $1 \mu \mathrm{g}$ of genomic DNA was bisulfite-converted using the Zymo Gold EZ DNA Methylation Kit (Zymo Research, Irvine, CA, USA) and eluted in a final volume of $25 \mu$ l. Then, $1 \mu \mathrm{l}$ of bisulphite-converted DNA was used for PCR amplification using the GoTaq Hot Start Polymerase (Promega, San Luis, CA, USA) and specific primers designed for bisulfite converted DNA sequences for each of the elements analyzed. PCR conditions and pyrosequencing primer sequences for L1HS, AluSx, and AluYb8 have been previously published by Yang et al. and by Choi et al. (Choi et al. 2009; Yang et al. 2004), while additional assays specific for L1PA5, L1PA2, and L1Ta, for the AluYd6 subfamily, and for the three HERV subfamilies (MLT1D, ERV1 and ERV9) were developed by Byun et al. (Byun et al. 2013). Primer sequences and PCR cycling conditions for each assay as well as number of $\mathrm{CpG}$ sites analyzed in each repetitive element are shown in Supplemental Material, Table S1. Finally, CpG methylation was evaluated by pyrosequencing. Samples were run in duplicate on the same day, and non-CpG cytosines in the analyzed sequence were used as controls to determine the efficiency of bisulfite-conversion. To control repeatability of the assay, we filled a well in each plate with a known fully methylated DNA sequence and another with a fully unmethylated DNA sequence. The percentage of methylation was expressed for each $\mathrm{CpG}$ site as the $\% 5$-mC divided by the sum of methylated and unmethylated cytosines.

\subsection{Statistical Analysis}

Correlations between adjacent $\mathrm{CpG}$ sites within each element were tested by Spearman rank correlations. Average correlations of $\mathrm{CpG}$ sites within the same repetitive element ranged from 0.15 to 0.76 (Supplemental Material, Table S2) and therefore we decided to use CpG position as a random effect rather than averaging methylation across sites, similarly to what has been suggested by other authors (Burris et al. 2012).

To explore sex differences in DNA methylation two-sample t-tests with unequal variances or Mann-Whitney U tests were performed accordingly.

TEXB-alpha presented a non-normal right skewed distribution (see Supplemental Material, Figure S1) with 31 samples below the LOD $(0.01 \mathrm{pM} \mathrm{Eeq} / \mathrm{ml})$ which were assigned values of LOD/2. We then created sex-specific TEXB-alpha tertiles which allowed us to explore possible nonlinear dose-response effects at different levels of exposure, as described for several EDCs (Vandenberg et al. 2012).

A linear mixed-effects regression model was used to estimate the association between tertiles of TEXB-alpha and absolute changes in percentage of DNA methylation in each repetitive element. Restricted Maximum Likelihood estimates were used to test random effect parameters using the Wald z-test. Significant individual random effects included in 
the final models were specified to take into account the correlation between technical replicates from the same individual (duplicates) and the different means of methylation between sites in the same element ( $\mathrm{CpG}$ position).

TEXB-alpha tertiles and a priori selected covariates (child sex and cohort) were included as fixed coefficients. The fully adjusted model additionally included maternal age, prepregnancy body mass index, and smoking during pregnancy, selected because of previous knowledge to impact both DNA methylation and TEXB levels (Morales et al. 2012; Vilahur et al. 2013b).

We used the following model:

$$
Y_{\mathrm{i}, \mathrm{j}, \mathrm{k}}=\beta_{0}+\beta_{1 \mathrm{TEXB}}+\beta_{2} \mathrm{X}_{2}+\cdots+\beta_{\mathrm{p}} x_{\mathrm{p}}+v_{0 \mathrm{i}}+v_{1 \mathrm{j}}+v_{2 \mathrm{k}}+\varepsilon_{\mathrm{ijk}}
$$

$\mathrm{Y}_{\mathrm{i}, \mathrm{j}, \mathrm{k}}$ represents the mean methylation level of all the $\mathrm{CpG}$ sites at any of the repetitive elements investigated for the $\mathrm{i}$-th subject, the $\mathrm{j}$-th duplicate run and the $\mathrm{k}$-th $\mathrm{CpG}$ position $(i=1, \ldots, 192 ; j=1,2$ and $k=1, \ldots, 5)$.

To explore possible effect modification by sex we introduced an infant sex interaction term to the multivariable mixed-effect regression models.

Considering the number of associations explored, a total of 20, the threshold for significant effects was set at a p-value below 0.0025 after applying Bonferroni correction for multiple testing.

Analyses were conducted using STATA 10.1 statistical software (Stata Corporation, College Station, TX).

\section{RESULTS}

\subsection{Demographic characteristics, TEXB and DNA methylation levels}

Main characteristics of mother and children of the study population are presented in Table 1. Mothers showed medium to high educational level, low prevalence of smoking habits during pregnancy and a mean age of around 32 years, similar to what we observe in the rest of the mothers from the INMA cohort for whom placenta was not available $(\mathrm{n}=2017)$ (data not shown). There was an equal distribution of sex among the newborns included in our study (49.48\% boys).

Overall and sex-specific levels of TEXB-alpha tertiles, expressed in estrogen equivalent units per gram of placenta (pM Eeq/g), are shown in Table 2. Mean placental DNA methylation levels for each repetitive element analyzed and estimated evolutionary age are shown in Supplemental Material, Table S1. Older retrotransposons had lower average DNA methylation levels than younger ones except for the MLT1D element, DNA methylation levels for LINE1 and AluYb8 were similar to what has previously been described in placenta (Armstrong et al. 2014; Wilhelm-Benartzi et al. 2012) and lower than in whole blood as shown by other authors (Armstrong et al. 2014; Byun et al. 2013). We explored differences in DNA methylation between boys and girls, comparing the mean methylation across all the 
$\mathrm{CpG}$ sites analyzed for each element. Boys presented on average significantly higher methylation levels compared to girls for 5 of the 10 repetitive elements studied, namely the three Alus and two of the HERV elements (ERV1 and ERV9) (Table 3).

\subsection{Association of TEXB-alpha levels and LINE, Alu and HERV DNA methylation}

We used a linear mixed-effects regression model to estimate associations between repetitive element DNA methylation and TEXB-alpha exposure, taking the first tertile (T1) as the reference (Table 4).

After correcting for multiple testing ( $\mathrm{p}$ value $=0.0025$ ) no significant associations were found between exposure to TEXB-alpha and any of the repetitive elements analyzed when considering boys and girls together. However, methylation of two LINEs showed associations with TEXB-alpha exposure that did not pass multiple testing threshold: TEXBalpha exposure in the second tertile resulted in a $0.81 \%$ decrease in L1HS DNA methylation ( $p$ value $=0.003$ ), while exposure in the third tertile produced on average an increase in L1PA5 DNA methylation of $0.99 \%$ ( $p$ value $=0.003$ ) in children when compared with TEXB-alpha in the first tertile. When we explored effect modification by sex, we observed a significant male-specific negative association between AluYb8 methylation and TEXB-alpha ( $\mathrm{p}$ value interaction $<0.001$ ) (Table 5). Boys with higher levels of TEXB-alpha (third tertile) had on average a decrease in methylation of $0.84 \%$ compared to boys in the first tertile $(\mathrm{p}$ value $=0.001$, while no significant effects were found in girls $(\beta=0.30$, $p$-value $=0.08)$. Mean methylation level for each $\mathrm{CpG}$ site analyzed of the AluYb8 element is shown by TEXBalpha tertile in boys and girls separately in Supplemental Material, Table S3. We did not find statistically significant sex interactions for the other Alu elements analyzed (AluSx and AluYd6), but marginally significant sex interactions according to our $\mathrm{p}$ value threshold were observed for two LINE elements, L1PA2 and L1Ta. In both cases, methylation levels tended to decrease in boys and increase in girls upon exposure to TEXB-alpha (Supplemental Material, Table S4).

\section{DISCUSSION}

This is the first epidemiological study analyzing the association between a biomarker of prenatal exposure to mixtures of xenoestrogens and DNA genome-wide methylation of retrotransposons in placenta including a large number of retrotransposons and exploring effect modification by sex. We found a statistically significant association between exposure to TEXB-alpha and AluYb8 repetitive element DNA methylation: boys in the highest tertile of TEXB-alpha presented on average a decrease of $0.84 \%$ in methylation compared to boys in the first tertile, while no effects were found in girls.

Two previous epidemiological studies in adults with smaller sample sizes have analyzed the effects on blood LINE-1 and Alu DNA methylation of exposure to POPs such as organochlorine (OC) pesticides and several of its by-products, which are lipophilic compounds accounted by the TEXB-alpha biomarker. In the first study, Rusiecky et al. found a significant negative association between POPs concentrations and AluSx DNA methylation in a population of highly exposed adult Greenlandic Inuit ( $\mathrm{n}=70,87 \%$ males) (Rusiecki et al. 2008). In the second study, a cross sectional design exploring the effect of 
low-dose OC pesticide exposure in a healthy adult Korean population $(\mathrm{n}=86)$, authors also found that environmental exposure was inversely associated with DNA methylation in the AluSx element (Kim et al. 2010). Although both studies find hypomethylation of an Alu element in relation to OC exposure, neither has specifically analyzed DNA methylation of the AluYb8 subfamily, nor explored sex interactions.

A balanced neonatal androgen:estrogen ratio is critical during prenatal period for male sexual differentiation and for the establishment of brain sexual differences during early development (Arnold 2009; Fernandez et al. 2007; Lenz et al. 2012). A growing body of evidence in humans suggests that sex differences may arise in epigenetic responses to prenatal environmental exposures (Gabory et al. 2009), and animal studies have suggested that effects may persist over generations (Anway et al. 2005).

Although probably EDCs will produce some of their adverse effects on health by interfering with the binding of endogenous steroid hormones to nuclear receptors in order to regulate gene expression (Bulzomi and Marino 2011), genome-wide methylation reshaping as a result of increased oxidative stress has been postulated as an alternative mechanism. Some environmental toxins, including POPs and other endocrine disruptors like Bisphenol A, can affect mitochondrial function and cause pro-oxidative conditions (D'Cruz et al. 2012; Lim et al. 2010; Yang et al. 2009). During pro-oxidant states, homocysteine is diverted away from the methionine cycle and toward the production of glutathione, leading to a deficiency in methyl donors and genome-wide DNA hypomethylation (Hitchler and Domann 2009; Madrigano et al. 2011). Supporting this hypothesis, there is a study showing a decrease in AluYb8 DNA methylation from buccal cells in prenatally exposed children to tobacco smoke, a known source of oxidative stress (Breton et al. 2009). A fine regulation of global methylation states is important in the development and function of extraembryonic tissues (Nelissen et al. 2011), and experimentally induced alterations in global DNA methylation affect placental weight in rats and disrupt trophoblast proliferation and migration (Rahnama et al. 2006; Serman et al. 2007).

Additionally, hypomethylation of repetitive elements contributes to loss of genomic stability, which is believed to result in somatic retrotranposition and insertional mutations (Romanish et al. 2010; Wilson et al. 2007). Disease events due to retrotransposition are mainly caused by the younger Alu elements, mostly the AluYa5, AluYb8 and AluYs subfamilies (Hancks and Kazazian 2012), which are the most active retrotransposons in humans with $>1$ million copies. We found that $A l u Y b 8$, the repetitive element associated with TEXB-alpha exposure in boys in the present study, had higher levels of DNA methylation in placenta than other elements, similarly to what others have reported (Armstrong et al. 2014; Wilhelm-Benartzi et al. 2012) and likely explained by its younger evolutionary age and higher $\mathrm{CpG}$ content (Choi et al. 2009). There is evidence that retrotransposons can serve as alternative promotors in several genes (van de Lagemaat et al. 2003; Waterland and Jirtle 2003). Retrotransposon transcription has a key influence upon the transcriptional output of the mammalian genome (Faulkner et al. 2009) and hypomethylation of repetitive elements has been associated with alterations of expression of particular genes (Morgan et al. 1999; Wolff et al. 2010). 
The methylation assay used in this study provides a cumulative measure of DNA methylation of repetitive element sequences dispersed throughout the genome (Yang et al. 2004). Thus, the change in DNA methylation observed for $A l u Y b 8$ in boys might represent a very small genome-wide change in methylation levels or alternatively a more pronounced change in one particular region. Although small, the effect size is similar to what other studies have reported analyzing either methylation of LINE-1 and several Alu retrotransposons or the global content of genomic 5'-methyl-deoxycytidine in relation to aging, prenatal tobacco smoke exposure and air pollution in blood, buccal cells and placenta (Bollati et al. 2009; Breton et al. 2009; Janssen et al. 2013; Madrigano et al. 2011).

We found that boys had significantly higher levels of methylation in all the Alu elements and in two of the endogenous retroviruses analyzed, similarly to previous literature that reported increased AluSx and AluYb8 DNA methylation in boys compared to girls in total blood and in placenta tissue, with methylation differences in the same range of what we have reported (around 1\% increase) (El-Maarri et al. 2007; Rusiecki et al. 2008; Wilhelm-Benartzi et al. 2012). Although the origin of these sex differences in repetitive elements methylation remains unsolved, the origin may reside in the $\mathrm{X}$ chromosomes. Some have postulated that there may be a factor in the $\mathrm{X}$ chromosome inducing hypomethylation that escapes proper inactivation in the female $\mathrm{Xi}$ ( $\mathrm{X}$ inactive) chromosome, or alternatively that the epigenetic "resources" necessary to maintain a whole chromosome inactive in females may result in less resources to properly methylate autosomal loci (El-Maarri et al. 2007).

\section{Limitations}

An important source of confounding in epigenetic studies may arise from the difference in cell composition of the tissue studied across samples (Jacoby et al. 2012). This is particularly relevant in the context of blood, composed of a variety of different cell subtypes with unique DNA methylation profiles (Houseman et al. 2012; Reinius et al. 2012), but it may be less problematic for tissues like the parenchymal villous of the human placenta, which is mainly dominated by mesenchymal-derived fibroblasts and trophoblasts. There are no epidemiological studies so far that have dissected different placental cell types and studied their specific DNA methylation patterns. However, cell heterogeneity may have impacted the effect size observed in our results (Liu et al. 2013).

Although in our study placentas were not frozen at $-80^{\circ} \mathrm{C}$ immediately after delivery in a standardized way, which is a common situation in the context of human epidemiological studies, we have previously shown that retrotransposon DNA methylation analyzed by bisulfite pyrosequencing remains stable in relation to time to storage delay at room temperature for up to 24 hours (Vilahur et al. 2013a), unlike what happens in more labile biological marks such as RNA or protein levels (Adibi et al. 2009; Ferrer et al. 2007).

\section{CONCLUSIONS}

The present study shows an association between increasing levels of in utero exposure to xenoestrogens and lower placental AluYb8 DNA methylation in boys, both analyzed in the same tissue, which may provide some clues regarding the molecular effects triggered by exposure to mixtures of hormonally active compounds commonly found in the environment 
and the differential susceptibility among males and females. Additionally, how xenoestrogens may modify the epigenome of specific genes deserves further investigation.

\section{Supplementary Material}

Refer to Web version on PubMed Central for supplementary material.

\section{Acknowledgments}

Funding

This work was supported by grants from the Spanish Ministry of Health (FIS-PI042018; FIS-PI060867; FISPI081151; FIS-PI09/02311; FIS-PI09/02647; FIS-PI11/00610]; Instituto de Salud Carlos III [Red INMA G03/176 and CB06/02/0041]; the EU Commission (QLK4-1999-01422, QLK4-2002-00603 and CONTAMED FP7ENV-212502), the Generalitat de Catalunya-CIRIT [1999SGR 00241]; the Fundació La Marató de TV3; the Consejería de Salud de la Junta de Andalucía (183/07 and 0675/10), the Diputación Foral de Gipuzkoa (DFG06/004), the Department of Health of the Basque Government (2005111093), the University of Oviedo, Obra Social Cajastur, and the Fundación Roger Torné. NV was supported by an FPI Grant from the Spanish Ministry of Health (BES-2009-023933) and a Formación de Personal Investigador Grant for Short Research Stays in Foreign Institutions (BES-2009-023933). AA Baccarelli receives support from the Harvard School of Public Health and National Institute of Environmental Health Sciences Center for Environmental Health (ES000002).

The HUSC BioBank, integrated in the Andalusia Public Health System (SSPA) and the National Biobank Network, is financed by the Institute of Health Carlos III, (RD09/0076/00148) and the Regional Government of Andalucia.

The authors acknowledge the study participants for their generous collaboration. A full roster of INMA Study Investigators can be found at: http://www.proyectoinma.org/presentacion-inma/listado-investigadores/listadoinvestigadores.html

The authors thank Dr. Georgia Escaramis for her useful comments on statistical methods.

\section{Abbreviations}

$\begin{array}{ll}\text { INMA } & \text { Infancia y Medio Ambiente Project } \\ \text { TEXB } & \text { Total Effective Xenoestrogen Burden } \\ \text { LOD } & \text { Limit of Detection } \\ \text { LINE } & \text { Long Interspersed Nuclear Element } \\ \text { SINE } & \text { Short Interspersed Nuclear Element } \\ \text { HERV } & \text { Human Endogenous Retrovirus } \\ \text { POPs } & \text { Persistent Organic Pollutants } \\ \text { EDCs } & \text { Endocrine Disrupting Compounds }\end{array}$

\section{Bibliography}

Adibi JJ, Hauser R, Williams PL, Whyatt RM, Thaker HM, Nelson H, et al. Placental biomarkers of phthalate effects on mrna transcription: Application in epidemiologic research. Environmental health : a global access science source. 2009; 8:20. [PubMed: 19389254]

Anway MD, Cupp AS, Uzumcu M, Skinner MK. Epigenetic transgenerational actions of endocrine disruptors and male fertility. Science. 2005; 308:1466-1469. [PubMed: 15933200]

Arnold AP. The organizational-activational hypothesis as the foundation for a unified theory of sexual differentiation of all mammalian tissues. Hormones and behavior. 2009; 55:570-578. [PubMed: 19446073] 
Arrebola JP, Fernandez MF, Olea N, Ramos R, Martin-Olmedo P. Human exposure to p, $\mathrm{p}^{\prime}-$ dichlorodiphenyldichloroethylene ( $\mathrm{p}, \mathrm{p}^{\prime}$-dde) in urban and semi-rural areas in southeast spain: A gender perspective. The Science of the total environment. 2013a; 458-460:209-216.

Arrebola JP, Pumarega J, Gasull M, Fernandez MF, Martin-Olmedo P, Molina-Molina JM, et al. Adipose tissue concentrations of persistent organic pollutants and prevalence of type 2 diabetes in adults from southern spain. Environmental research. 2013b; 122:31-37. [PubMed: 23290489]

Bollati V, Schwartz J, Wright R, Litonjua A, Tarantini L, Suh H, et al. Decline in genomic DNA methylation through aging in a cohort of elderly subjects. Mech Ageing Dev. 2009; 130:234-239. [PubMed: 19150625]

Breton CV, Byun HM, Wenten M, Pan F, Yang A, Gilliland FD. Prenatal tobacco smoke exposure affects global and gene-specific DNA methylation. American journal of respiratory and critical care medicine. 2009; 180:462-467. [PubMed: 19498054]

Bulzomi P, Marino M. Environmental endocrine disruptors: Does a sex-related susceptibility exist? Front Biosci (Landmark Ed). 2011; 16:2478-2498. [PubMed: 21622190]

Burris HH, Rifas-Shiman SL, Baccarelli A, Tarantini L, Boeke CE, Kleinman K, et al. Associations of line-1 DNA methylation with preterm birth in a prospective cohort study. J Dev Orig Health Dis. 2012; 3:173-181. [PubMed: 22720130]

Byun HM, Motta V, Panni T, Bertazzi PA, Apostoli P, Hou L, et al. Evolutionary age of repetitive element subfamilies and sensitivity of DNA methylation to airborne pollutants. Particle and fibre toxicology. 2013; 10:28. [PubMed: 23855992]

Callinan PA, Batzer MA. Retrotransposable elements and human disease. Genome Dyn. 2006; 1:104115. [PubMed: 18724056]

Collotta M, Bertazzi PA, Bollati V. Epigenetics and pesticides. Toxicology. 2013; 307:35-41. [PubMed: 23380243]

Cotton AM, Avila L, Penaherrera MS, Affleck JG, Robinson WP, Brown CJ. Inactive x chromosomespecific reduction in placental DNA methylation. Human molecular genetics. 2009; 18:35443552. [PubMed: 19586922]

Choi SH, Worswick S, Byun HM, Shear T, Soussa JC, Wolff EM, et al. Changes in DNA methylation of tandem DNA repeats are different from interspersed repeats in cancer. Int J Cancer. 2009; 125:723-729. [PubMed: 19437537]

D'Cruz SC, Jubendradass R, Mathur PP. Bisphenol a induces oxidative stress and decreases levels of insulin receptor substrate 2 and glucose transporter 8 in rat testis. Reprod Sci. 2012; 19:163-172. [PubMed: 22101236]

El-Maarri O, Becker T, Junen J, Manzoor SS, Diaz-Lacava A, Schwaab R, et al. Gender specific differences in levels of DNA methylation at selected loci from human total blood: A tendency toward higher methylation levels in males. Hum Genet. 2007; 122:505-514. [PubMed: 17851693]

Erlandsson R, Wilson JF, Paabo S. Sex chromosomal transposable element accumulation and maledriven substitutional evolution in humans. Molecular biology and evolution. 2000; 17:804-812. [PubMed: 10779541]

Fernandez MF, Olmos B, Granada A, Lopez-Espinosa MJ, Molina-Molina JM, Fernandez JM, et al. Human exposure to endocrine-disrupting chemicals and prenatal risk factors for cryptorchidism and hypospadias: A nested case-control study. Environmental health perspectives. 2007; 115(Suppl 1):8-14. [PubMed: 18174944]

Ferrer I, Santpere G, Arzberger T, Bell J, Blanco R, Boluda S, et al. Brain protein preservation largely depends on the postmortem storage temperature: Implications for study of proteins in human neurologic diseases and management of brain banks: A brainnet europe study. J Neuropathol Exp Neurol. 2007; 66:35-46. [PubMed: 17204935]

Frederiksen M, Vorkamp K, Mathiesen L, Mose T, Knudsen LE. Placental transfer of the polybrominated diphenyl ethers bde-47, bde-99 and bde-209 in a human placenta perfusion system: An experimental study. Environmental health : a global access science source. 2010; 9:32. [PubMed: 20598165]

Fucic A, Gamulin M, Ferencic Z, Katic J, Krayer von Krauss M, Bartonova A, et al. Environmental exposure to xenoestrogens and oestrogen related cancers: Reproductive system, breast, lung, 
kidney, pancreas, and brain. Environmental health : a global access science source. 2012; 11(Suppl 1):S8. [PubMed: 22759508]

Gabory A, Attig L, Junien C. Sexual dimorphism in environmental epigenetic programming. Mol Cell Endocrinol. 2009; 304:8-18. [PubMed: 19433243]

Graff JR, Herman JG, Myohanen S, Baylin SB, Vertino PM. Mapping patterns of cpg island methylation in normal and neoplastic cells implicates both upstream and downstream regions in de novo methylation. J Biol Chem. 1997; 272:22322-22329. [PubMed: 9268383]

Guerrero-Bosagna C, Covert TR, Haque MM, Settles M, Nilsson EE, Anway MD, et al. Epigenetic transgenerational inheritance of vinclozolin induced mouse adult onset disease and associated sperm epigenome biomarkers. Reprod Toxicol. 2012; 34:694-707. [PubMed: 23041264]

Guerrero-Bosagna C, Savenkova M, Haque MM, Nilsson E, Skinner MK. Environmentally induced epigenetic transgenerational inheritance of altered sertoli cell transcriptome and epigenome: Molecular etiology of male infertility. PloS one. 2013; 8:e59922. [PubMed: 23555832]

Guxens M, Ballester F, Espada M, Fernandez MF, Grimalt JO, Ibarluzea J, et al. Cohort profile: The inma--infancia y medio ambiente--(environment and childhood) project. Int J Epidemiol. 2012; 41:930-940. [PubMed: 21471022]

Hancks DC, Kazazian HH Jr. Active human retrotransposons: Variation and disease. Curr Opin Genet Dev. 2012; 22:191-203. [PubMed: 22406018]

Hitchler MJ, Domann FE. Metabolic defects provide a spark for the epigenetic switch in cancer. Free Radic Biol Med. 2009; 47:115-127. [PubMed: 19362589]

Houseman EA, Accomando WP, Koestler DC, Christensen BC, Marsit CJ, Nelson HH, et al. DNA methylation arrays as surrogate measures of cell mixture distribution. BMC Bioinformatics. 2012; 13:86. [PubMed: 22568884]

Ibarluzea Jm J, Fernandez MF, Santa-Marina L, Olea-Serrano MF, Rivas AM, Aurrekoetxea JJ, et al. Breast cancer risk and the combined effect of environmental estrogens. Cancer Causes Control. 2004; 15:591-600. [PubMed: 15280638]

Jacoby M, Gohrbandt S, Clausse V, Brons NH, Muller CP. Interindividual variability and coregulation of DNA methylation differ among blood cell populations. Epigenetics. 2012; 7:14211434. [PubMed: 23151460]

Janssen BG, Munters E, Pieters N, Smeets K, Cox B, Cuypers A, et al. Placental mitochondrial DNA content and particulate air pollution during in utero life. Environmental health perspectives. 2012; 120:1346-1352. [PubMed: 22626541]

Janssen BG, Godderis L, Pieters N, Poels K, Kici Ski M, Cuypers A, et al. Placental DNA hypomethylation in association with particulate air pollution in early life. Particle and fibre toxicology. 2013; 10:22. [PubMed: 23742113]

Kile ML, Baccarelli A, Hoffman E, Tarantini L, Quamruzzaman Q, Rahman M, et al. Prenatal arsenic exposure and DNA methylation in maternal and umbilical cord blood leukocytes. Environmental health perspectives. 2012; 120:1061-1066. [PubMed: 22466225]

Kim KY, Kim DS, Lee SK, Lee IK, Kang JH, Chang YS, et al. Association of low-dose exposure to persistent organic pollutants with global DNA hypomethylation in healthy koreans. Environmental health perspectives. 2010; 118:370-374. [PubMed: 20064773]

Klose RJ, Bird AP. Genomic DNA methylation: The mark and its mediators. Trends Biochem Sci. 2006; 31:89-97. [PubMed: 16403636]

Lander ES, Linton LM, Birren B, Nusbaum C, Zody MC, Baldwin J, et al. Initial sequencing and analysis of the human genome. Nature. 2001; 409:860-921. [PubMed: 11237011]

Lenz KM, Nugent BM, McCarthy MM. Sexual differentiation of the rodent brain: Dogma and beyond. Front Neurosci. 2012; 6:26. [PubMed: 22363256]

Lim S, Cho YM, Park KS, Lee HK. Persistent organic pollutants, mitochondrial dysfunction, and metabolic syndrome. Annals of the New York Academy of Sciences. 2010; 1201:166-176. [PubMed: 20649553]

Liu Y, Aryee MJ, Padyukov L, Fallin MD, Hesselberg E, Runarsson A, et al. Epigenome-wide association data implicate DNA methylation as an intermediary of genetic risk in rheumatoid arthritis. Nat Biotechnol. 2013; 31:142-147. [PubMed: 23334450] 
Macia A, Munoz-Lopez M, Cortes JL, Hastings RK, Morell S, Lucena-Aguilar G, et al. Epigenetic control of retrotransposon expression in human embryonic stem cells. Mol Cell Biol. 2011; 31:300-316. [PubMed: 21041477]

Madrigano J, Baccarelli A, Mittleman MA, Wright RO, Sparrow D, Vokonas PS, et al. Prolonged exposure to particulate pollution, genes associated with glutathione pathways, and DNA methylation in a cohort of older men. Environmental health perspectives. 2011; 119:977-982. [PubMed: 21385671]

Manikkam M, Tracey R, Guerrero-Bosagna C, Skinner MK. Plastics derived endocrine disruptors (bpa, dehp and dbp) induce epigenetic transgenerational inheritance of obesity, reproductive disease and sperm epimutations. PloS one. 2013; 8:e55387. [PubMed: 23359474]

Migeon BR, Axelman J, Jeppesen P. Differential x reactivation in human placental cells: Implications for reversal of $x$ inactivation. American journal of human genetics. 2005; 77:355-364. [PubMed: 16080112]

Morales E, Bustamante M, Vilahur N, Escaramis G, Montfort M, de Cid R, et al. DNA hypomethylation at alox12 is associated with persistent wheezing in childhood. American journal of respiratory and critical care medicine. 2012; 185:937-943. [PubMed: 22323304]

Morgan HD, Sutherland HG, Martin DI, Whitelaw E. Epigenetic inheritance at the agouti locus in the mouse. Nature genetics. 1999; 23:314-318. [PubMed: 10545949]

Nelissen EC, van Montfoort AP, Dumoulin JC, Evers JL. Epigenetics and the placenta. Hum Reprod Update. 2011; 17:397-417. [PubMed: 20959349]

Papadopoulou E, Vafeiadi M, Agramunt S, Mathianaki K, Karakosta P, Spanaki A, et al. Maternal diet, prenatal exposure to dioxins and other persistent organic pollutants and anogenital distance in children. The Science of the total environment. 2013; 461-462:222-229.

Pilsner JR, Hall MN, Liu X, Ilievski V, Slavkovich V, Levy D, et al. Influence of prenatal arsenic exposure and newborn sex on global methylation of cord blood DNA. PloS one. 2012; 7:e37147. [PubMed: 22662134]

Puertas R, Lopez-Espinosa MJ, Cruz F, Ramos R, Freire C, Perez-Garcia M, et al. Prenatal exposure to mirex impairs neurodevelopment at age of 4 years. Neurotoxicology. 2010; 31:154-160. [PubMed: 19818364]

Rahnama F, Shafiei F, Gluckman PD, Mitchell MD, Lobie PE. Epigenetic regulation of human trophoblastic cell migration and invasion. Endocrinology. 2006; 147:5275-5283. [PubMed: 16887905]

Reinius LE, Acevedo N, Joerink M, Pershagen G, Dahlen SE, Greco D, et al. Differential DNA methylation in purified human blood cells: Implications for cell lineage and studies on disease susceptibility. PloS one. 2012; 7:e41361. [PubMed: 22848472]

Rogers J. Retroposons defined. Nature. 1983; 301:460. [PubMed: 6185851]

Romanish MT, Cohen CJ, Mager DL. Potential mechanisms of endogenous retroviral-mediated genomic instability in human cancer. Semin Cancer Biol. 2010; 20:246-253. [PubMed: 20685251]

Rusiecki JA, Baccarelli A, Bollati V, Tarantini L, Moore LE, Bonefeld-Jorgensen EC. Global DNA hypomethylation is associated with high serum-persistent organic pollutants in greenlandic inuit. Environmental health perspectives. 2008; 116:1547-1552. [PubMed: 19057709]

Serman L, Vlahovic M, Sijan M, Bulic-Jakus F, Serman A, Sincic N, et al. The impact of 5azacytidine on placental weight, glycoprotein pattern and proliferating cell nuclear antigen expression in rat placenta. Placenta. 2007; 28:803-811. [PubMed: 17509679]

Tajuddin SM, Amaral AF, Fernandez AF, Rodriguez-Rodero S, Rodriguez RM, Moore LE, et al. Genetic and non-genetic predictors of line-1 methylation in leukocyte DNA. Environmental health perspectives. 2013; 121:650-656. [PubMed: 23552396]

Tan J, Loganath A, Chong YS, Obbard JP. Exposure to persistent organic pollutants in utero and related maternal characteristics on birth outcomes: A multivariate data analysis approach. Chemosphere. 2009; 74:428-433. [PubMed: 18986677]

Toppari J, Larsen JC, Christiansen P, Giwercman A, Grandjean P, Guillette LJ Jr, et al. Male reproductive health and environmental xenoestrogens. Environmental health perspectives. 1996; 104(Suppl 4):741-803. [PubMed: 8880001] 
Vafeiadi M, Agramunt S, Papadopoulou E, Besselink H, Mathianaki K, Karakosta P, et al. In utero exposure to dioxins and dioxin-like compounds and anogenital distance in newborns and infants. Environmental health perspectives. 2013; 121:125-130. [PubMed: 23171674]

Valvi D, Mendez MA, Martinez D, Grimalt JO, Torrent M, Sunyer J, et al. Prenatal concentrations of polychlorinated biphenyls, dde, and ddt and overweight in children: A prospective birth cohort study. Environmental health perspectives. 2012; 120:451-457. [PubMed: 22027556]

Valvi D, Mendez MA, Garcia-Esteban R, Ballester F, Ibarluzea J, Goni F, et al. Prenatal exposure to persistent organic pollutants and rapid weight gain and overweight in infancy. Obesity (Silver Spring). 2013

van de Lagemaat LN, Landry JR, Mager DL, Medstrand P. Transposable elements in mammals promote regulatory variation and diversification of genes with specialized functions. Trends Genet. 2003; 19:530-536. [PubMed: 14550626]

Vandenberg LN, Colborn T, Hayes TB, Heindel JJ, Jacobs DR Jr, Lee DH, et al. Hormones and endocrine-disrupting chemicals: Low-dose effects and nonmonotonic dose responses. Endocrine reviews. 2012; 33:378-455. [PubMed: 22419778]

Vilahur N, Baccarelli AA, Bustamante M, Agramunt S, Byun HM, Fernandez MF, et al. Storage conditions and stability of global DNA methylation in placental tissue. Epigenomics. 2013a; 5:341-348. [PubMed: 23750648]

Vilahur N, Molina-Molina JM, Bustamante M, Murcia M, Arrebola JP, Ballester F, et al. Male specific association between xenoestrogen levels in placenta and birthweight. Environment international. 2013b; 51:174-181. [PubMed: 23262415]

Webster TF. Mixtures of endocrine disruptors: How similar must mechanisms be for concentration addition to apply? Toxicology. 2013

WHO WHO. International programme on chemical safety. 2002. Global assessment of the state-ofthe-science of endocrine disruptors.

WHO WHO. An assessment of the state of the science of endocrine disruptors prepared by a group of experts for the united nations environment programme (unep) and who. 2013. State of the science of endocrine disrupting chemicals-2012; p. 296

Wilhelm-Benartzi CS, Houseman EA, Maccani MA, Poage GM, Koestler DC, Langevin SM, et al. In utero exposures, infant growth, and DNA methylation of repetitive elements and developmentally related genes in human placenta. Environmental health perspectives. 2012; 120:296-302. [PubMed: 22005006]

Wilhelm CS, Kelsey KT, Butler R, Plaza S, Gagne L, Zens MS, et al. Implications of line1 methylation for bladder cancer risk in women. Clin Cancer Res. 2010; 16:1682-1689. [PubMed: 20179218]

Wilson AS, Power BE, Molloy PL. DNA hypomethylation and human diseases. Biochim Biophys Acta. 2007; 1775:138-162. [PubMed: 17045745]

Wolff EM, Byun HM, Han HF, Sharma S, Nichols PW, Siegmund KD, et al. Hypomethylation of a line-1 promoter activates an alternate transcript of the met oncogene in bladders with cancer. PLoS genetics. 2010; 6:e1000917. [PubMed: 20421991]

Wright RO, Schwartz J, Wright RJ, Bollati V, Tarantini L, Park SK, et al. Biomarkers of lead exposure and DNA methylation within retrotransposons. Environmental health perspectives. 2010; 118:790-795. [PubMed: 20064768]

Yang AS, Estecio MR, Doshi K, Kondo Y, Tajara EH, Issa JP. A simple method for estimating global DNA methylation using bisulfite pcr of repetitive DNA elements. Nucleic Acids Res. 2004; 32:e38. [PubMed: 14973332]

Yang YJ, Hong YC, Oh SY, Park MS, Kim H, Leem JH, et al. Bisphenol a exposure is associated with oxidative stress and inflammation in postmenopausal women. Environmental research. 2009; 109:797-801. [PubMed: 19464675] 


\section{Highlights}

- Few epidemiologic studies have analyzed effects of mixtures of hormonally active compounds

- We measured a biomarker of prenatal cumulative exposure to xenoestrogens

- We examined its relationship with DNA methylation of repetitive elements in placenta

- Higher levels of xenoestrogens were associated with lower AluYb8 methylation in boys 


\section{Table 1}

Maternal and children demographic characteristics

\begin{tabular}{|c|c|c|}
\hline & $\mathbf{N}$ & $\%$ or mean $(\mathrm{SD})$ \\
\hline \multicolumn{3}{|l|}{ Mothers } \\
\hline \multicolumn{3}{|c|}{ Active smoking during pregnacny } \\
\hline no & 159 & 84.13 \\
\hline$<=5$ cigarettes/day & 16 & 8.47 \\
\hline$>5$ cigarettes/day & 14 & 7.41 \\
\hline \multicolumn{3}{|l|}{ Parity } \\
\hline primiparous & 110 & 56.21 \\
\hline multiparous & 82 & 43.79 \\
\hline \multicolumn{3}{|l|}{ Cohort } \\
\hline Asturias & 33 & 17.19 \\
\hline Gipuzkoa & 64 & 33.33 \\
\hline Sabadell & 70 & 36.46 \\
\hline Valencia & 25 & 13.02 \\
\hline \multicolumn{3}{|l|}{ Education } \\
\hline < secondary school & 34 & 17.71 \\
\hline secondary school & 89 & 46.35 \\
\hline university degree & 69 & 35.94 \\
\hline Age $(y)$ & 192 & $31.83(3.94)$ \\
\hline Body mass index (BMI) & 192 & $23.39(4.07)$ \\
\hline \multicolumn{3}{|l|}{ Children } \\
\hline \multicolumn{3}{|l|}{$\operatorname{Sex}$} \\
\hline male & 97 & 49.48 \\
\hline female & 95 & 50.52 \\
\hline Birth weight $(g)$ & 191 & $3301(411.03)$ \\
\hline Gestational age (weeks) & 189 & $39.82(1.34)$ \\
\hline
\end{tabular}




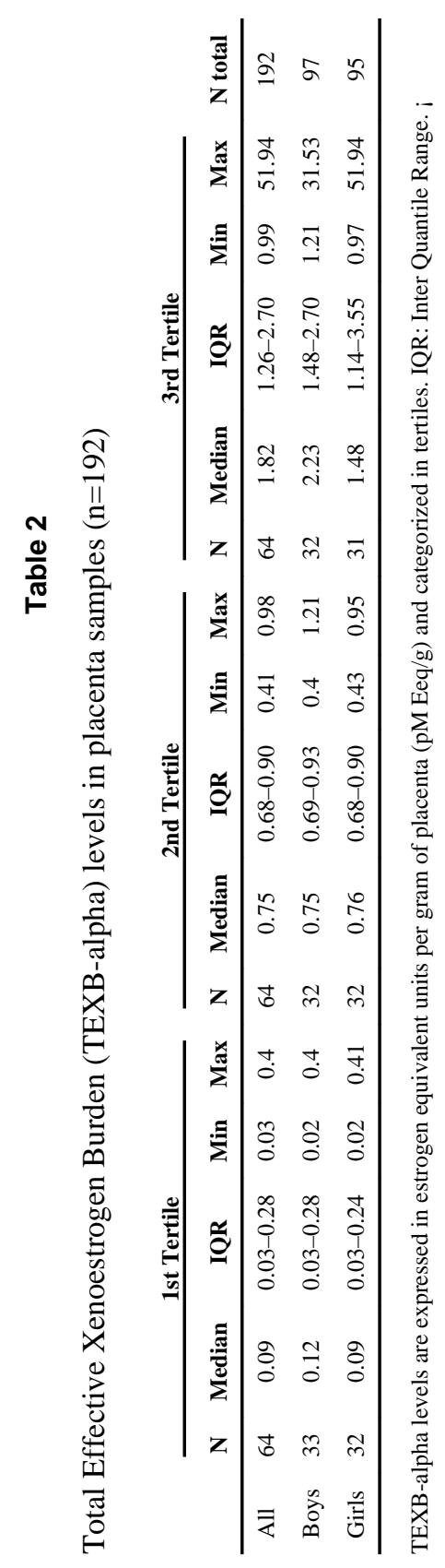


Table 3

Differences in average mean methylation levels between boys and girls for the ten repetitive elements analyzed

\begin{tabular}{|c|c|c|c|c|}
\hline & \multirow[t]{2}{*}{ Repetitive Element } & \multicolumn{2}{|c|}{ Mean \% methylation (SD) } & \multirow[t]{2}{*}{ p-value } \\
\hline & & Girls (n=97) & Boys (n=95) & \\
\hline \multirow[t]{4}{*}{ LINEs } & L1PA $5^{1}$ & $23.28(2.40)$ & $23.03(2.71)$ & 0.349 \\
\hline & L1PA2 1 & $44.37(2.57)$ & $43.98(2.77)$ & 0.159 \\
\hline & L1Hs & $55.42(2.92)$ & $55.35(2.99)$ & 0.639 \\
\hline & L1Ta & $50.32(3.09)$ & $50.37(3.26)$ & 0.862 \\
\hline \multirow[t]{3}{*}{ Alus } & AluSx 1 & $25.89(1.08)$ & $26.40(0.98)$ & $<0.001 *$ \\
\hline & AluYb8 ${ }^{1}$ & $82.91(1.80)$ & $83.50(1.91)$ & $0.001^{*}$ \\
\hline & AluYd6 & $65.14(3.1)$ & $66.25(3.00)$ & $0.004^{*}$ \\
\hline \multirow[t]{3}{*}{ HERVs } & MLT1D & $86.22(3.39)$ & $86.44(3.55)$ & 0.524 \\
\hline & ERV 1 & $17.22(2.34)$ & $17.56(1.97)$ & $0.004^{*}$ \\
\hline & ERV 91 & $49.48(5.74)$ & $49.83(2.64)$ & $<0.001 *$ \\
\hline
\end{tabular}




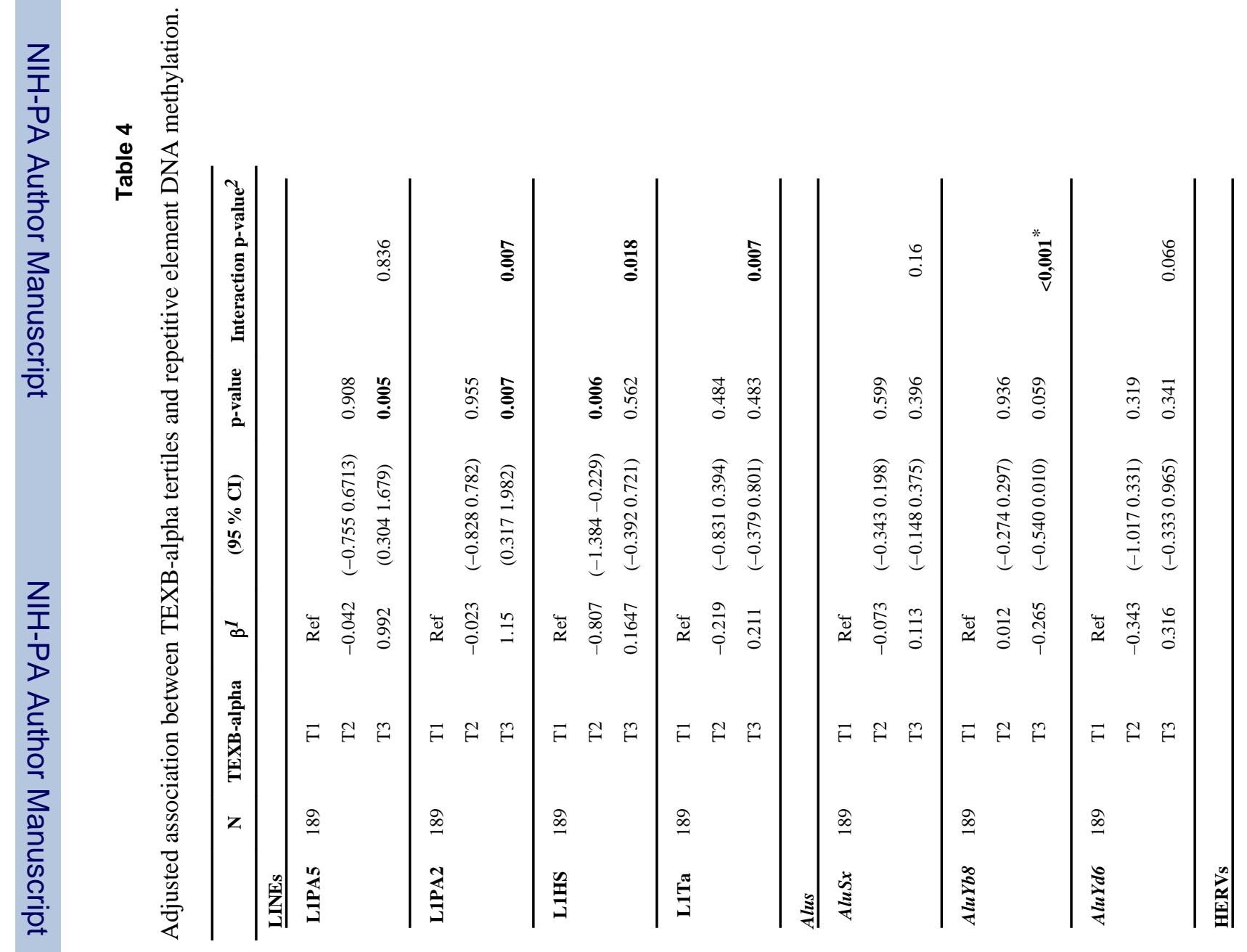




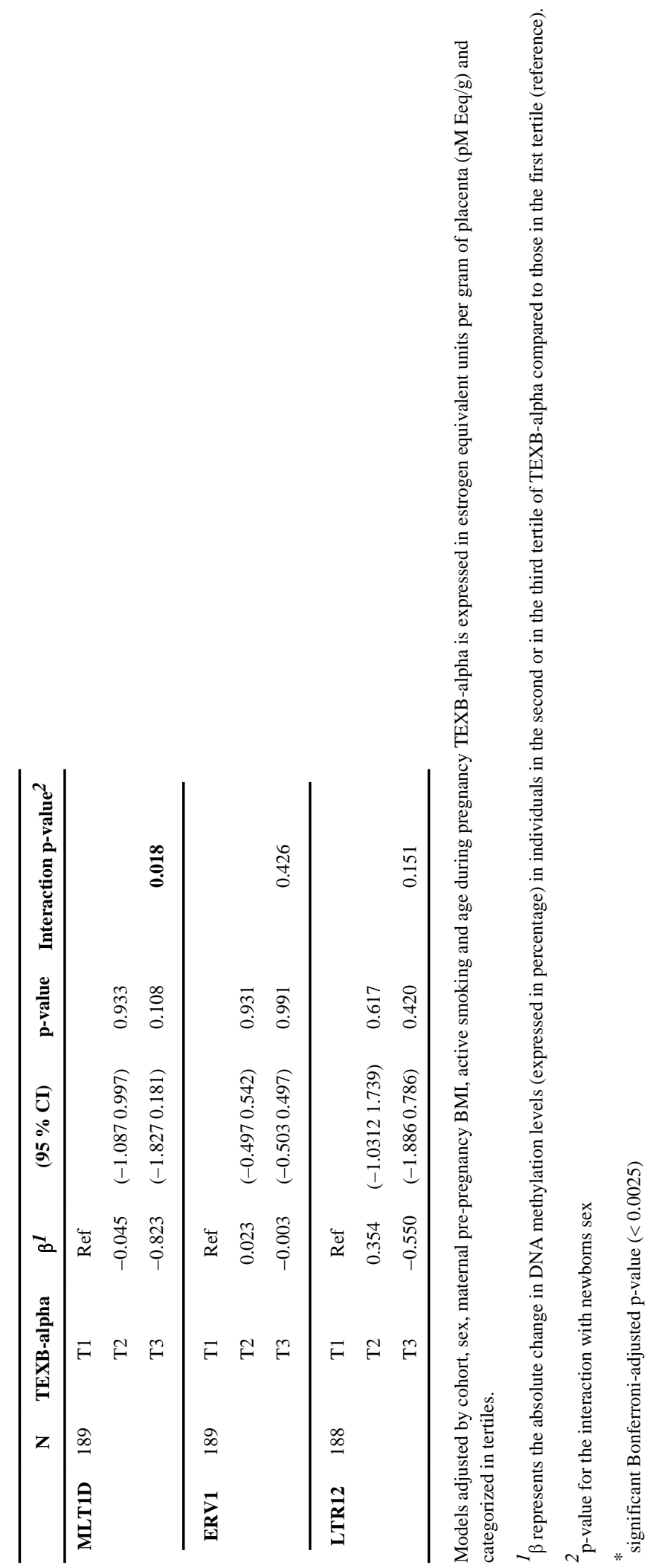




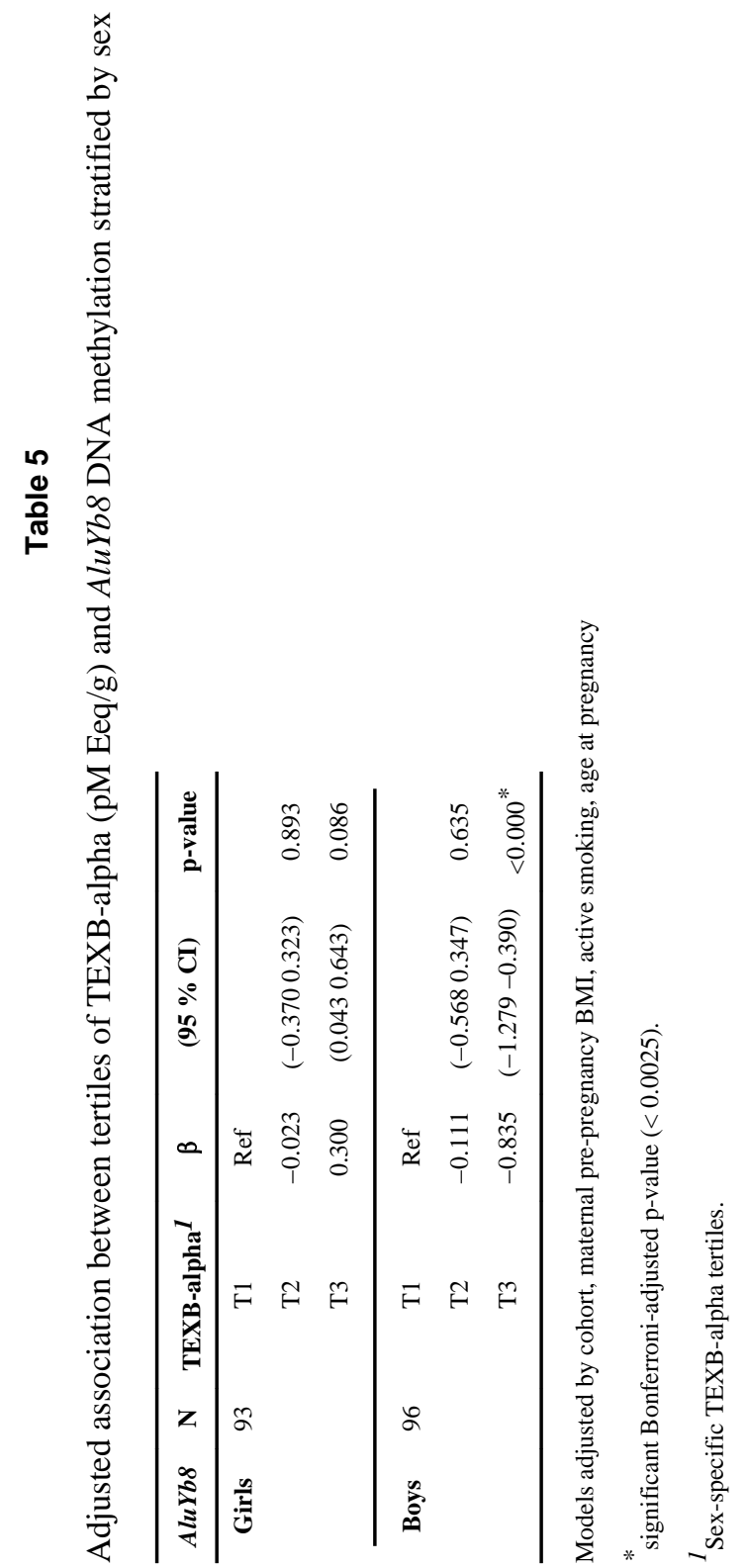

Environ Int. Author manuscript; available in PMC 2015 October 01. 